\title{
R (ON THE APPLICATION OF BEGUM) $v$ HEADTEACHER AND GOVERNORS OF DENBIGH HIGH SCHOOL HL [2006] UKHL 15, [2006] ALL ER (D) 320 (MAR), (APPROVED JUDGMENT)
}

\author{
The Jilbab Controversy
}

Susan Edwards ${ }^{*}$

\section{THE FACTS}

On March $22^{\text {nd }} 2006$, the House of Lords allowed an appeal by the defendant school, Denbigh High School in Luton and ruled that the school's uniform policy which disallowed a particular variation of Islamic dress - the "jilbab" (a long sleeved floor length loose fitting tunic dress) - did not amount to an interference with the respondent's right to manifest her religion. ${ }^{1}$ Denbigh High School's, school uniform, for those who were of the Islamic faith was in the form of the "shalwar kameeze" (a tunic and a particular style of shaped trousers). This uniform variation was worn by those Muslim girls who wished to wear it and was also worn by non-Muslim girls of Hindu and Sikh faiths who attended the school. Shabina Begum had attended the school since the age of eleven years and had worn the shalwar kameeze. When she was thirteen she no longer wished to wear the shalwar kameeze, instead she said she wanted to wear a jilbab which she maintained was "the appropriate" dress code for a Muslim woman after puberty. Moreover, she refused to attend school unless she could wear this form of dress.

The facts are set out in the House of Lords judgement: "On 3 September 2002, the first day of the autumn term, the respondent (then aged nearly 14 years) went to the school with her brother and another young man. They asked to speak to the head teacher, who was not available, and they spoke to the assistant head teacher, $\mathrm{Mr}$ Moore. They insisted that the respondent be

\footnotetext{
* BA (CNAA ), MA , PhD (Manc), LLM (Reading), Professor of Law, Deputy Dean of Law, University of Buckingham; Barrister, (Door Tenant) Clarendon Chambers 1 Plowden Buildings Temple, London EC4Y 9BU.

${ }^{1} R$ (on the application of Begum) $v$ Headteacher and Governors of Denbigh High School HL [2006] UKHL 15, [2006] All ER (D) 320 (Mar), (Approved judgment).
} 


\section{THE DENNING LAW JOURNAL}

allowed to attend the school wearing the long garment she had on that day, which was a long coat-like garment known as a jilbab."2

The school refused to allow her to attend unless she wore either the regular school uniform or the shalwar kameeze, and in December 2002, the school together with the Local Education Authority sought independent advice from Muslim experts regarding whether the shalwar kameeze as a variation of the school uniform 'offended' against the Islamic dress code. Two mosques in Luton, the London Central Mosque Trust and the Islamic Cultural Centre advised that the shalwar kameeze did not offend and conformed with the Islamic dress code.

On behalf of Shabina Begum opinions were sought from three sources (two of these were Imams who had been previously consulted by Denbigh High School) on the merits of the jilbab. They all maintained that the jilbab was "the appropriate dress for mature Muslim women." ${ }^{3}$ This information was passed on to the appellants, who refused to accept that this was "the appropriate" dress for women, and in September 2003 the Education Welfare Service offered to help her find a place at another school if that was what she wanted. In the same month, the school received a statement made by the Muslim Council of Britain on the "Dress code for women in Islam" which stated "there was no recommended style; modesty must be observed at all times; trousers with long tops or shirts for school wear were 'absolutely fine'." 4

Shabina Begum felt that she was being effectively excluded by not being allowed to attend school dressed in the jilbab, whilst the school, on the other hand, considered that they were not excluding her since a school place was available if she wore the shalwar kameeze. In October 2003, a committee of the school governors met and gave a lengthy decision upholding the head teacher's decision which required her to wear the school uniform or the prescribed variation of it.

\section{THE HIGH COURT}

Shabina Begum, issued her claim for judicial review on February 13, 2004 for leave first, to challenge the decision of the head teacher and the governors not to her admit if she insisted on wearing the jilbab and second, to challenge the consequence of this which was that Luton Borough Council was not providing her with education. Leave was granted but only to challenge the decision of the head teacher and governors. Shabina also

\footnotetext{
${ }^{2}$ Ibid per Lord Bingham, at para 10.

${ }^{3}$ Ibid at para 15.

${ }^{4}$ Ibid at para 15.
} 


\section{THE DENNING LAW JOURNAL}

contended that not allowing her to wear her preferred form of Islamic dress amounted to excluding her from school, and contravened article 9(1) of the European Convention for the Protection of Human Rights and Fundamental Freedoms 1950 (as set out in Schedule 1 to the Human Rights Act 1998). Article 9 asserts:

"1. Everyone has the right to freedom of thought, conscience and religion; this right includes freedom to change his religion or belief and freedom, either alone or in community with others and in public or private, to manifest his religion or belief, in worship, teaching, practice and observance. 2. Freedom to manifest one's religion or beliefs shall be subject only to such limitations as are prescribed by law and are necessary in a democratic society ... for the protection of the rights and freedoms of others.”

She argued that by not being allowed to wear the jilbab in school violated her right not to be denied education under art 2 of the First Protocol to the Convention, which states: "No person shall be denied the right to education. In the exercise of any functions which it assumes in relation to education and to teaching, the State shall respect the right of parents to ensure such education and teaching in conformity with their own religious and philosophical convictions."

Bennett $\mathrm{J}^{5}$ in the High Court held, that there was no breach of article 9(1) because "she was excluded for her refusal to wear the school uniform and not because of her religious belief." "In respect of the limitations Bennett $\mathrm{J}$ held, "in my judgment the school uniform policy and its enforcement has, and continues to have, a legitimate aim and is proportionate. The legitimate aim was the proper running of a multi-cultural, multi-faith, secular school. The limitation was also proportionate to the legitimate aim pursued."7

In interpretation of art 2 Bennett $\mathrm{J}$ was informed by A $v$ Headteacher and Governors of Lord Grey School ${ }^{8}$ (a case which involved the exclusion of Abdul Hakim from the Lord Grey School during the pendancy of criminal proceedings against him), Stanley Burnton $\mathrm{J}$ who heard the A case on transfer to the High Court, rejected A's claim that his right to education had been violated:

\footnotetext{
${ }^{5}$ The Times, June 18, 2004, [2004] EWHC 1389.

${ }^{6} \mathrm{HL}$ at para 74.

7 HL at para 91.

${ }^{8}$ [2003] 4 All ER 1317.
} 


\section{THE DENNING LAW JOURNAL}

“...it has to be borne in mind that the duty created by art 2 of the First Protocol is imposed on the state, and not on any particular domestic institution. It does not create a right to be educated in any particular institution or in any particular manner. Expulsion from a school of a pupil who has no access to alternative educational facilities, such as enrolment in another school or education through a pupil referral unit, may cause a breach of art 2 of the First Protocol, and if so, the school authority may be liable for damages; but if the pupil is able to have access to efficient education elsewhere, no breach of his convention right will be involved. If the cause of the unavailability of alternative efficient education is the action or inaction of the local education authority, on whom duties are imposed by ss 13 and 19(1) of the 1996 Act, it will be the local education authority, rather than the school authority, that will have caused the infringement of the pupil's rights under art 2 of the First Protocol. If suitable and adequate alternative educational facilities are available, but the pupil's parents decide that their child should not use them, then the local education authority will in general not have caused an infringement of art 2 of the First Protocol.”9

This argument appears to have been relied upon on by the High Court and the House of Lords when they accepted that Shabina Begum had access to other schools and was therefore not denied access to education. The High Court held that there would be no interference with the right under art 2 of the First Protocol unless there had been an exclusion on the grounds of religious belief. The court held that the right to be educated meant: "The right to be educated, not to be educated at a particular school." ${ }^{10}$ Shabina Begum's claim for judicial review against the defendant Denbigh High School was therefore dismissed.

\section{THE COURT OF APPEAL}

The Court of Appeal, (Lord Justices Brooke, Mummery, and Scott Baker $)^{11}$ decided differently from Bennett $\mathrm{J}$ in the High Court and made a declaration that art 9 had indeed been infringed on the grounds that Shabina Begum's freedom to manifest her religion or belief in public was being

\footnotetext{
${ }^{9}$ Ibid at 1337 , para 83 .

${ }^{10}$ Ibid at para 97.

${ }^{11}$ The Times, March 4, 2005; [2005] 1WLR 3372.
} 


\title{
THE DENNING LAW JOURNAL
}

limited. The Court of Appeal also held differently on where the burden of proof lay. Their view was that the burden rested on the school to justify its limitation on her freedom. The Court of Appeal also found that the school had excluded her without following the correct procedures. Brooke LJ said:

\begin{abstract}
"The school undoubtedly did exclude the claimant. They told her, in effect: 'Go away, and do not come back unless you are wearing proper school uniform'. They sent her away for disciplinary reasons ... and she was unable to return to the school for the same reason.” 12
\end{abstract}

The Court of Appeal elaborated upon what it considered the appropriate decision making structure ${ }^{13}$ (with which the House of Lords disagreed) which started out from the premise, “...that the claimant had a right which is recognised by English law, and that the onus lay on the School to justify its interference with that right." ${ }^{14}$ The Court of Appeal went on to say that if the school had approached the issue from the position that the claimant had a right under art 9(1) they may well have concluded that interference under art 9(2) was justified. ${ }^{15}$ Scott Baker LJ, went on to say, “...there is in my view force in the criticism that it is not for the school authorities to pick and choose between religious beliefs or shades of religious belief." "16 Mummery LJ said, (in contradistinction to Bennett $\mathrm{J}$ in the High Court): "It is irrelevant to the engagement of article 9 that the claimant could have changed to a school which accommodated her religious beliefs about dress." ${ }^{\prime 7}$ The Court of Appeal relied on Kokkinakis $v$ Greece, ${ }^{18}$ which held that: "Bearing witness in words or deeds is bound up with the existence of religious convictions...,"19

\section{THE HOUSE OF LORDS}

The House of Lords (per Lord Bingham of Cornhill, Lord Nicholls of Birkenhead Lord Hoffmann, Lord Scott of Foscote, and Baroness Hale of Richmond) upheld the decision of Bennett $\mathrm{J}$ in the High Court and held that art 9(1) the right to hold religious belief was inviolable, and that there had been no interference with the right to hold and manifest one's religion (Lord

\footnotetext{
12 Ibid [2005] 3378H-3379A, at para 24.

${ }^{13}$ Ibid per Brooke LJ 3390AB, at para 75.

${ }^{14}$ Ibid per Brooke LJ 3390C, at para 76.

${ }^{15}$ Ibid per Scott Baker LJ 3393CD, at para 92.

${ }^{16}$ Ibid 3393E, at para 93.

${ }^{17}$ Ibid $3391 \mathrm{H}$, at para 84.

18 (1993) 17 EHRR 397, at paras 31-32.

19 Ibid.
} 


\title{
THE DENNING LAW JOURNAL
}

Nicholls of Birkenhead and Baroness Hale of Richmond dissenting). Lord Bingham said:

\begin{abstract}
"The fundamental importance of this right in a pluralistic, multi-cultural society was clearly explained by my noble and learned friend Lord Nicholls of Birkenhead in $R$ (Williamson) $\checkmark$ Secretary of State for Education and Employment [2005] UKHL 15, [2005] 2 AC 246, paras 15-19, and by the South African Constitutional Court in Christian Education South Africa $v$ Minister of Education [2001] 1 LRC 441, para 36. This is not in doubt. As pointed out by my noble and learned friend in para 16 of the passage cited, article 9 protects both the right to hold a belief, which is absolute, and a right to manifest belief, which is qualified.” 20
\end{abstract}

Lord Nicholls of Birkenhead and Baroness Hale of Richmond dissented and found that there had been interference with respect to that part of art 9(1) - the right to manifest belief - although they held that the limitation of that right was justified under art 9(2) "for the protection of the rights and freedoms of others.”

The House of Lords (Lord Nicholls and Baroness Hale dissenting) also found that art 2 had not been breached because the school's uniform policy was to be obeyed and if the claimant did not like it, she could go to a different school. ${ }^{21}$ Lord Nicholls said:

"Your Lordships' reasons are twofold: (1) the school's refusal to allow Shabina Begum to wear a jilbab at school did not interfere with her article 9 right to manifest her religion and, even if it did, (2) the school's decision was objectively justified. I agree with the second reason. I am not so sure about the first. I think this may over-estimate the ease with which Shabina could move to another ...school.” 22

Baroness Hale said:

"I too agree that this appeal should be allowed. Most of your Lordships take the view that Shabina Begum's right to

\footnotetext{
${ }^{20} R$ (on the application of Begum) $v$ Headteacher and Governors of Denbigh High School HL [2006] UKHL 15, [2006] All ER (D) 320 (Mar), (Approved judgment) para 20.

${ }^{21}$ Ibid at para 24.

${ }^{22}$ Ibid at para 41.
} 


\section{THE DENNING LAW JOURNAL}

manifest her religion was not infringed because she had chosen to attend this school knowing full well what the school uniform was. It was she who had changed her mind about what her religion required of her, rather than the school, which had changed its policy. I am uneasy about this.” 23 [And] "I am therefore inclined to agree with my noble and learned friend, Lord Nicholls of Birkenhead, that there was an interference with Shabina Begum's right to manifest her religion."24

The House of Lords then went on to consider what constituted an interference within the meaning of art 9(2) and whether any interference was justified. In considering the matter of interference the House of Lords endeavoured to apply the Strasbourg jurisprudence in what they considered "a reasonable way" ${ }^{25}$ citing Kala $v$ Turkey, ${ }^{26}$ which held: "Art 9 does not protect every act motivated or inspired by a religion or belief. Moreover, in exercising his freedom to manifest his religion, an individual may need to take his specific situation into account., ${ }^{27}$ Applying too, Sahin $v$ Turkey, ${ }^{28}$ and Ahmad v United Kingdom ${ }^{29}$ which held: “. . . the freedom of religion, as guaranteed by Article 9, is not absolute, but subject to the limitations set out in Article 9(2). Moreover, it may, as regards the modality of a particular religious manifestation, be influenced by the situation of the person claiming that freedom." ${ }^{30}$ Strasbourg jurisprudence on art 9 had engaged a wide range of issues and from several and very different European countries and in each case the court concluded that there had been no interference. ${ }^{31}$

${ }^{23}$ Ibid at para 92.

${ }^{24}$ Ibid at para 93.

${ }^{25}$ Ibid at para 25.

${ }^{26}$ (1997) 27 EHRR 552.

27 HL at para 27.

${ }^{28}$ Application No 44774/98, 10 November 2005, unreported. Para 105.

${ }^{29}$ (1981) 4 EHRR 126, at para 11.

${ }^{30} \mathrm{HL}$ at para 86.

${ }^{31}$ In Denmark, $X v$ Denmark (1976) 5 DR 157, considered the question of the right of clergyman to leave the church, and Kjeldsen, Busk Madsen and Pedersen v Denmark (1976) 1 EHRR 711, considered parent's religious objection to sex education. The UK case of Ahmad $v$ United Kingdom (1981) 4 EHRR 126, considered the right of teachers to be asbent from school for prayers. In Konttinen $v$ Finland (1996) 87-A DR 68 , the issues raised was whether working hours conflicted with religious convictions. In Valsamis $v$ Greece (1996) 24 EHRR 294, a child who was a Jehovah's witness who was punished for refusing to attend national day parade was held not to be an interference. In Karaduman v Turkey (1993) 74 DR 93, the applicant was denied a certificate of graduation because a photograph of her without a headscarf was 


\section{THE DENNING LAW JOURNAL}

The House of Lords also considered the Court of Appeal's criticism of this line of Strasbourg authority as "overly restrictive." Lord Bingham responded by saying:

"Even if it be accepted that the Strasbourg institutions have erred on the side of strictness in rejecting complaints of interference, there remains a coherent and remarkably consistent body of authority which our domestic courts must take into account and which shows that interference is not easily established.” 32

The House of Lords accepted that interference was a debatable question "which gives the issue of justification under art 9(2) particular significance.”33 Lord Bingham then went on to consider whether the school's approach to the uniform question was justified. He said:

"To be justified under art 9(2) a limitation or interference must be (a) prescribed by law and (b) necessary in a democratic society for a permissible purpose, that is, it must be directed to a legitimate purpose and must be proportionate in scope and effect, the issue is whether the rules and the school's insistence on them were in all the circumstances proportionate." 34

The House of Lords held the Court of Appeal's approach to procedure to have been wrong and the House of Lords in its judgment referred to three academic articles which also shared this view ${ }^{35}$ and also to the fact that

required and she was unwilling for religious reasons to be photographed without a headscarf. In Stedman $v$ United Kingdom (1997) 23 EHRR CD 168, there was no interference where an employee was free to resign rather than work on Sundays. In Jewish Liturgical Association Cha'are Shalom Ve Tsedek v France (2000) 9 BHRC 27, para 81, also failed where the applicant's case was that ritual slaughter of meat in France did not meet religious requirements. In all the above cases no interference was established.

${ }^{32} \mathrm{HL}$ at para 24.

${ }^{33} \mathrm{HL}$ at para 25.

${ }^{34} \mathrm{HL}$ at para 26.

${ }^{35}$ See Poole, "Of headscarves and heresies: The Denbigh High School case and public authority decision making under the Human Rights Act" [2005] PL 685; Linden and Hetherington, "Schools and Human Rights" [2005] Educational Law Journal 229; and, for a more controversial appraisal, Davies, "Banning the Jilbab: Reflections on Restricting Religious Clothing in the Light of the Court of Appeal in SB v Denbigh High School (2005) 1.3 European Constitutional Law Review 511. 


\section{THE DENNING LAW JOURNAL}

shortly after the Court of Appeal judgement the Secretary of State intervened in order to correct what he described, as a fundamental misunderstanding of the Human Rights Act. And in so doing, Lord Bingham enumerated three reasons why he considered the Court of Appeal's approach to the procedural question wrong.

"First, the purpose of the Human Rights Act 1998 was not to enlarge the rights or remedies of those in the United Kingdom whose Convention rights have been violated but to enable those rights and remedies to be asserted and enforced by the domestic courts of this country... [30]. Secondly, it is clear that the court's approach to an issue of proportionality under the Convention must go beyond that traditionally adopted to judicial review in a domestic setting...[31]. Thirdly, ... I consider that the Court of Appeal's approach would introduce "a new formalism" and be "a recipe for judicialisation on an unprecedented scale"...... But what matters in any case is the practical outcome, not the quality of the decision-making process that led to it." 36

The House of Lords criticised the Court of Appeal's approach to this procedural question and said that the importance of preserving an inclusive uniform and preserving harmony was a legitimate aim and the refusal of Shabina Begum's request to wear the jilbab proportionate to that aim and justified. "The school was entitled to consider that the rules about uniform were necessary for the protection of the rights and freedoms of others." 37

\section{COMMENT}

The House of Lords in this case was very careful in ruling that its finding applied to the Denbigh High School case and to no other.

" It is important to stress at the outset that this case concerns a particular pupil and a particular school in a particular place at a particular time. It must be resolved on facts, which are now, for purposes of the appeal, agreed. The House is not, and could not be, invited to rule whether Islamic dress, or any feature of Islamic dress, should or should not be permitted in the schools of this country. That would be a most

\footnotetext{
${ }^{36} \mathrm{HL}$ at para 29.

${ }^{37} \mathrm{HL}$ at para 58 per Lord Hoffman.
} 


\section{THE DENNING LAW JOURNAL}

inappropriate question for the House in its judicial capacity, and it is not one, which I shall seek to address.”38

The House of Lords decision clearly steers well clear of making any general rules with regard to school uniform and manifestation of religious belief. There is no need for future cases to follow the House of Lords or to distinguish or overrule. The House of Lords also avoided any discussion with regard to the meaning of 'manifestation' and 'observance' in art 9(1) preferring to rely on the wording and approach of the Strasbourg jurisprudence. Although it is to be noted that the Strasbourg jurisprudence on the point of 'dress code' has considered 'manifestation' in a very specific context, relying on cases emanating from Turkey. Here, the particular social situation is coloured by the politico-religious and historical context of Turkey's recent efforts towards modernity. Begum's social situation even taking into account the politico-historical context, that is, Islamic dress in the United Kingdom is a far, far, cry from Turkey's history and struggle towards modernisation and its particular version of secularisation, which the Court of Appeal in contradistinction to the House of Lords found to be, putting it at its lowest, 'overly restrictive' and at its highest, prohibitive.

Interestingly, the House of Lords was concerned with in Lord Bingham's words practical outcomes in approaching the proportionality question. Nicholas Blake QC (sitting as a deputy High Court judge) in $R$ (Baker) v First Secretary of State ${ }^{39}$ characterised the process requirements as part of proportionality itself. "Proportionality is not simply whether at the end result the balance is fair, but whether, in getting there, it has been decided that the most appropriate course of conduct is also the least interfering with human rights, having regard to the public benefit to be achieved and the different means of achieving it."

The law has often been driven by consequences rather than by principle as Simon Lee has demonstrated ${ }^{40}$ and here, in this case, the consequences are set in a context of minority versus majority rights and a minority position that has been variously understood as 'orthodox', 'extremist' and 'fundamentalist' even though such language has been deliberately avoided by the courts. All courts, High Court, Appeal Court and House of Lords avoided any discussion of this question and their positionality on this issue was veiled in their eschewing of the use of terms like "moderate" or "extreme," using instead the nomenclature of "very strong religious beliefs" 41 explaining: "For the purposes of this judgment, because the epithet 'fundamentalist' has

\footnotetext{
${ }^{38} \mathrm{HL}$ at para 2.

${ }^{39}$ [2003] EWHC 2511, [2004] JPL 729 (n 77).

${ }^{40}$ S. Lee Judging Judges, (London: Faber and Faber 1989).

${ }^{41} \mathrm{CA}$ at 3376 para 8.
} 


\section{THE DENNING LAW JOURNAL}

resonations which it would be inappropriate to carry into the discussion of the issues in this difficult case I will refer to those Muslims who believe that it is mandatory for women to wear the jilbab as 'very strict Muslims' and those Muslims who consider it inappropriate dress for a woman as 'liberal Muslims' While being conscious that experts might find these epithets equally inappropriate." 42

The balance between the rights of Shabina Begum and the rights and freedoms of others (Muslim girls and Muslim young women) came down on the side of protecting the rights of others (Muslim girls and Muslim young women) from coming under 'any pressure' from within or outside the school to wear the same form of dress as Shabina Begum wished to wear. This is an interesting logic to protect others from a particular pressure. If applied in the context of the everyday life, a similar argument would follow in respect of any religious group. It would be an argument applicable to the pressure real or imagined placed on Muslim girls and Muslim young women to wear the headscarf - the hijab - or indeed to wear the shalwar kameeze. The wearing of the headscarf one might argue has already marked out Muslim girls and Muslim young women one from another, in so far as hijab wearers might be considered to be outwardly manifesting a claim to a more orthodox Islamicism. $^{43}$

\footnotetext{
${ }^{42} \mathrm{CA}$ at 3381 para 33.

${ }^{43}$ Miss Booth QC's point HL at para 65.
} 
THE DENNING LAW JOURNAL 